\title{
Between the Strange and the Familiar: A Journey with the Motel
}

\author{
RANDALl TEAL
}

Fleeing with a suitcase of stolen cash, Llewelyn Moss reaches the anonymous safety of a motel. Once in his hiding place, he unscrews a vent cover and stashes the money in an air duct. However, before he can complete this task, he hears shots in the room next door. For Moss, the motel is but a tenuous respite from the dangers of his world.

Images like this from Joel and Ethan Cohen's film No Country for Old Men hang like a specter over the roadside motel. The media "history" of the motel frequently augments the motel's material character and serves to color our physical encounters with it. Images of the motel in film can be seen as dramatic elaboration of the motel's fundamental peculiarity as a cultural and material phenomenon. In this way film amplifies potentialities already embodied in the motel that run the gamut from a dark place of immoral dealings to a spartan place of dwelling.

In December 2006 I was invited to create an art installation that interpreted the meaning and nature of the motel room. ${ }^{1}$ Immediately, the tension between the strange and the familiar aspects of the motel struck me as a special determinant of its identity. Principally, I wanted to explore the line that separates the strange and the familiar and the way in which the motel as a "between" serves as the site of coalescence for these forces. This betweenness of the motel is structured by it being neither fully "homely" nor "unhomely."2 In fact, the motel's betweenness is exactly that which affords the visitor an opportunity to become homely within its walls. This 
paper explores how the motel's impermanence, imperfection, and vaguely tragic character propel it toward a position where it can offer a surprisingly satisfying and supportive human environment.

\section{Images on the Edge}

If we look closely at a concrete example-a French café for instance-it is obvious that its essential nature is only partly revealed in its visible appearance; for the most part that essence is hidden in the field of references to the social and cultural life related to the place (Vesely 77).

Our relationships to the motel are fueled by many different images: some personal, some typological, some topological, and some cultural. Images arise both from experiences of lodgings past and the visions of popular media. In these experiences, the motel can take on a variety of guises: it has been seen as a place that binds segments of a journey, a location for a meeting, an oasis, and occasionally even a prison. At times it can be unclear as to whether the motel's character has simply played as fodder for creative storytelling, or if imaginative representations have actually helped to form the mythology of the motel and our experience of it therein.

In film the motel is often seen as a place separate from the context it is associated with, suspended somewhere between civilization and wilderness. This is not so different from how we tend to experience the motel. This portrayal helps to make these images believable, as they are both recognizable and seductive. Although there are times when the motel appears simply as a stopping point in a journey, frequently it becomes a site of intensification: that is to say, the specific material presence of the motel is used to amplify an already loaded situation. For example, in Wim Wender's Paris, Texas, the motel serves as a poignant revelation of transiency framing Travis's re-appearance and subsequent flight; in Michael Kang's The Motel, a run-down 
motel becomes the site holding open a dysfunctional city within a city; and in other films such as David Lynch's Lost Highway, the presence of the motel focuses a general sense of alienation, showing itself to be a self-referential no-place. In becoming the location of its own world, the motel stands as the destination where one comes off the road but never really arrives anywhere except the motel itself. Here the motel is portrayed as a location that is inseparable from the journey.

The particular no-place-ness of the motel is sometimes used in film for positive augmentation as well. In Wes Anderson's Bottle Rocket, for example, despite being on the run, Luke Wilson's character finds love, an event which is heightened by the generic backdrop of the motel and the emptiness of its location. However, more frequently films take up the no-placeness of the motel for more foreboding ends: the motel portrayed as an outpost that provides the thinnest of assurances against nefarious forces lurking close by. This vision of the ominous noplace is rendered in exemplary fashion (under numerous guises) in No Country for Old Men, where it seems the motel becomes the very crucible for misdeeds and violent encounter. In this film the motel not only sets the mood for bloodshed but superbly reflects the questionable level of protection its walls offer from the dangers of the world as experienced by the film's protagonist, Llewelyn Moss.

For the active imagination, this image of the motel at the edge of humanity is frequently the most affectual of the motel's possibilities-usually hauntingly so. The list of potential disreputable deeds supported by the motel seems endless:

Motels are places for assignations and illicit sex, for planning crimes and dividing the spoils, for insecure people in transit or desperate people on the run. There's always the chance that you'll wake up alone, robbed after a night of passion, or that the place will be surrounded by cops ... and you've the choice of shooting it out or getting handcuffed (French, para. 4). 
Baleful visions of the motel have played out over the years in numerous film acts: the murder in Psycho, the kidnapping in A Touch of Evil, the alcoholic stupor in Leaving Las Vegas, the ambush in The Way of the Gun, the illegal interrogations and murder in L.A. Confidential, and of course the repeating motif of hunter hunted in No Country for Old Men. It seems that these sinister dealings gain intensity by their association with the motel; and simultaneously, the habitable potential of the motel is called into question.

\section{The Necessity of the Tragic}

As a building type the very essence of the motel is that of loss. That is to say, at its most basic level the motel is a place where no one will ever remain. Its recurring reality is that of always being left behind by the beloved traveler. In this perpetual coupling and departing, the room and guest act out the brief romance and eventually suffer the inevitable death of departure. There is something about this persistent aura of passing-away that helps to make the motel a place that is both somewhat disturbing and yet strangely compelling. Perhaps the nondescript motel actually needs the flux of the visitor to remain vital. In the motel, as in life, beginnings and ends and play out over and over, with every crossing of a threshold signaling the same tragic cycle.

In the film imagery discussed above one witnesses the tragic essence of the motel being magnified and expressed in quite literal and dramatic ways. However, there is also a less pointed understanding of the tragic. In contrast to the larger-than-life modern tragic, the Greek tragic was experienced as an event where "virtually nothing occurs" (Heidegger, Holderlin's Hymn 103). This is to say, the Greek tragic was not carried out with the same hyperbole as the modern tragic, and this distinction adds a wrinkle to understanding the tragic in the motel. Unlike the tragic 
motel of film, the tragic essence of the motel in everyday experience is its unhomeliness: it provides a microcosm of a vulnerable and contingent life. The visitor who is confronted by and accepts this condition is provided an opportunity to overcome habitual behaviors, thus allowing the world once again to become new. Invoking the Greek understanding of the tragic, Friedrich Nietzsche affects the voice of tragedy to remind us of this vitalizing function:

Be as I am! Amid the ceaseless flux of phenomena I am the eternally creative primordial mother, eternally impelling to existence, eternally finding satisfaction in this chance of phenomena! (104)

As Nietzsche suggests, a constant overturning of situations is experienced as the "tragedy" of passing. Yet, passing is also a becoming. The interplay between the uncanny feeling of loss and the energizing feeling of creation signals the vibrancy of mortal existence.

The roadside motel is a location inextricably linked to a journey and this fact affirms its fundamental relation to the temporal and thus the tragic. The temporality of the motel is the foundation for its betweenness, that is, being a site of both the homely and the unhomely. Negotiating the homely and the unhomely is what allows the visitor to dwell at the motel. Heidegger explains this saying, "dwelling itself, being homely, is the becoming homely of a being unhomely" (Holderlin's Hymn 137). In order to understand this statement more fully it becomes necessary to examine what is unhomely about the motel.

\section{Out of Place}

The unhomely of the motel is prefigured by its primary domain in the margins. As a building type, the motel does not seek dialogue with its environment, instead preferring autonomy and repetition. Christian Norberg-Schulz has suggested that "if we do not possess an

environmental image we just ramble about without any sense of belonging" (The Concept of 
Dwelling 66). So it is that the motel shows its lack of environmental image through its standardization of form and ubiquitous roadside presence. This particular strategy of engagement contributes to the motel's conspicuousness, making it stand out as specifically "motel" in most locations. In other words, when found in a place with a greater sense of environmental continuity the motel is frequently experienced as "other."

Otherness from place is the beginning of the uncanny in the motel and is structured by the distinctive manner in which the motel connects with its environment. This connection reveals a fundamental difference between the motel and the hotel, where the latter often aspires to represent context in a meaningful way (i.e., view, activities), cultivating an interrelation with its greater environment. The motel does not make this attempt; instead of being of a place, the motel is its own place, one that is both generically specific and specifically generic. In this disposition there arises a difference in kind between the motel and the hotel. For example, a hotel in Greenwich Village stands as a particular intensification of the city, a place of venturing forth, an initiation for deeper incursions into the city. In contrast, the roadside motel in its fundamental relation to the highway has journeying as its destination. The motel blurs the line between tarrying and traveling.

Indeed, given the singularity and consistency of this relation, it could be argued that the motel is actually an extension of the highway itself. In his discussions of Holderlin's "Ister Hymn," Heidegger explains that "the river 'is' the locality that pervades the abode of human beings upon the earth, determines them to where they belong and where they are homely" (21). In a strange way the motel/highway becomes a journeying location similar to that of the river where: 
[t]he essence of the locale, in which becoming homely finds its point of departure and its point of entry, is such that it journeys ... the locale is both here and there, not according to some contingency but under the concealed law of a journey (35).

This phenomenon occurs as roads reach out into the "nowhere" of the urban margins. At intervals these roads slacken and gather as restaurants, gas stations, convenience stores, and motels. The sharpness of the motel's "otherness" from either city or country is merely a continuation of the otherness of the highway system and its manifestation as an overlay upon the landscape. The otherness of the system is witnessed in both the motel's more traditional and contemporary manifestations. Wayne Curtis points out that despite an often wistful view of the heyday of the road motel, even in the early days it was given particular identity by its relation to the highway:

Historic Route 66 enters Amarillo, Texas, from the northeast, on a strip lined with seedy motels and fast-food restaurants. This is Route 66 in its older-Elvis phase, bloated and decadent and festooned with baubles. Photos of areas like this always accompany newspaper articles about the horrors of unmanaged development, and a drive down this stretch is a good antidote for syrupy nostalgia over the pre-interstate era (para. 1).

The story has not changed significantly with the inception of the modern interstate system. Curtis goes on to describe a contemporary scenario where the characters are different but the results are much the same:

Most visitors to Amarillo these days arrive on Interstate 40, which skirts the southern edge of the city center and has numerous exits that slough drivers onto mysterious and vexing frontage roads. These are the natural habitat of the chain motel, and La Quinta, Travelodge, Fairfield Inn, and Econolodge all offer accommodations here (para. 2).

As "man-made works must necessarily set up a relationship with what already exists" it seems inevitable that the roadside motel should be exactly the way that it is (Norberg-Schulz, Architecture 159). Being an extension of road it follows that the gatherings of motels and other franchises associated with the highway would appear alien to their greater context, in the sense 
that they are not incorporated or in communication with what Norberg-Schulz calls the "genius loci" of the existing environment (Genius Loci). Yet if understood from the point of view that the road is its domain, it seems that the motel does in fact effectively reveal the genius loci of its place. The motel is the place of the highway.

Despite a lack of greater environmental response the motel still offers a profound connection to the outside world. This connection is the apotheosis of its uncanniness. Unlike a hotel where one enters the building and then walks down an internal hallway to the room, the road motel does not offer this buffer. In the motel one is not insulated against the no-place just beyond the edge of one's room. In fact this no-place seems to pulse just beyond the curtains that separate the bed from the parking lot (and whatever else might be waiting in the dark). Here lies an unusually fertile ground for the imagination. The fact is that one is palpably upon the public world where seemingly anyone could knock upon your door or worse yet, enter your room (as Javier Bardiem's character does on multiple occasions in No Country for Old Men). As opposed to the hotel, with its inner keep, there are no layers of privacy for the motel room. The brittle boundary that separates the haven of the room from the potential dangers of the outside world gives the motel a memorable, if not disconcerting, connection to place that is paradoxically both placed and placeless. Here the motel folds back upon itself and in so doing begins to determine its own aesthetic.

The generic materiality of the motel room helps to cement this aesthetic and root it somewhere between homely and unhomely. Here the motel's potency is heightened by those things that one would normally call its liabilities: the standardization of form, the "common" décor, the dislocation from context, the association with the car, and the fact that primary views are typically of the motel itself, its own parking lot, and the strangers who walk directly by the 
windows of its rooms. The motel room is unique in its lack of privacy, especially for a place that is ostensibly set up for those human acts that necessitate the most privacy. Yet in embracing its own deficiencies, the motel gains experiential presence. While one might not normally think of these seeming undesirable qualities to be positive features, the real vulnerability and oddity of the motel helps to carve it into our mythology. As a journey and location the roadside motel reveals the strange unhomeliness of a foreign environment to the traveler. In this revealing, "becoming homely in what is one's own becomes possible." (Heidegger, Holderlin's Hymn 21) The unhomely is the basis of the motel as dwelling place.

\section{Motel as Dwelling}

'Dwelling' is practically and technically regarded as the possession of accommodation and housing. Such things indeed belong to dwelling, yet they do not fulfill or ground its essence. Dwelling takes on an abode and is an abiding in such an abode... the abode is a whiling. It needs a while. In such a while human beings find rest. Yet rest here does not mean the cessation of activity or the halting of disruption (Heidegger, Holderlin's Hymn 20).

Heidegger has posited that "dwelling is the basic character of being" ("Building Dwelling Thinking" 109). The motel, like other fundamental forms of shelter, holds within itself the potential to be engaged at this primordial level. However, this notion of dwelling will not be found in the nostalgic symbols of "home." Dwelling understood simply as "home" misses something more basic that is not activated through mere solicitation or superficial affectation. When nostalgic appliqué stands in to represent "home" an avoidance of the uncanny is exposed. ${ }^{3}$ The uncanny state of being human is lived through dwelling as the process of coming to terms with contingency and vulnerability. In this way being human amounts to the fact that we find ourselves in constant need of reorientation to ever-changing situations. Dwelling occurs as a 
condition between the extremes of anxiety and routine. Dwelling is being-in-the-world and is experienced as this familiar/strange state of human existence. It is this vision of dwelling as something that is in perpetual negotiation with the familiar and the strange that provides the greatest insight into the power of the motel.

As an abode for the "whiling" of dwelling, the motel shows itself not as an environment that is lacking or one in which dwelling occurs in a deficient manner, but rather as the perfect environment for dwelling. The transient, generic, and displaced aspects of the motel provide the necessary confrontation with the unhomely as the first step in the process of dwelling. Showing itself to be unhomely, the motel asks that the visitor give up a view of home as something that is eternal and unchanging.

Dwelling is put into motion through encounter with the unique combination of the specifically odd and the expectedly generic. The strange familiarity of this combination serves as the catalyst for becoming homely. For example, although speaking of a hotel, motel historian Andy Wood's quip, "there's something very comforting about knowing that, at midnight on a Friday night, you can go into a Holiday Inn cocktail lounge and sing karaoke,” provides a vivid sense of how this weird combination of expectation and idiosyncrasy ground the motel in the homely and unhomely (Bly, "Come Inn"). And yet in order to understand the motel it is important to not focus on the homely and unhomely as objects of a duality; as Heidegger reminds us, "locality and journeying ... implicate one another in a properly peculiar way. It is of decisive importance, yet at the same time difficult to think their unity" (Holderlin's Hymn 52). For the motel, "thinking unity" means that strangeness is its homeliness.

Temporality lies at the foundations of the motel's unity. The temporal frees the motel from the static image of home and allows it to interface directly with dwelling as something that 
is always on the way. In other words, the less the motel tries to be the picture of "home" the more effective it becomes as a place of dwelling. It does this by not attempting to fix one's existence to a single location or avoid the unhomely; rather, its spareness brings the visitor face to face with what is uncanny in being away from home. Consequently when one comes to accept and work within the limitations of the unhomely motel, basic amenities open up and afford an opportunity for dwelling, for becoming homely. Elaborating on Heidegger's essay "Building Dwelling Thinking," Kenneth Frampton provides direction for understanding how the motel offers this orientation:

Heidegger argues that the phenomenological essence of such a space/place depends on the concrete clearly defined by the nature of its boundary, for as he puts it, a boundary is not that at which something stops but as the Greeks recognized, the boundary is that from which something begins its presencing ... the condition of dwelling and hence ultimately being can only take place in a domain that is clearly bounded (27).

Recognizing a boundary as that which allows presencing provides a slightly different perspective on the vulnerability felt in the minimal separation between the motel room and the outside world. Taking the typical understanding of the boundary as the region where something ends has the tendency to emphasize the room's edge as holding back the unknown of the shared public world. In terms of dwelling this traditional view would seem to suggest that the more secure the separation the better to facilitate dwelling. However, if one reverses this view of a boundary, then it first becomes apparent what the motel room offers. In contrast to the uncertainties, transiency, and vastness of the outside world, the threshold of the room announces the presencing of something personal, intimate, and comforting. This presencing is made more intense by the thinness of the edge as the difference between realms becomes tangible. In other words the invitation to dwell is intensified by the room's nearness to the surrounding world. Here the motel room offers a " ... guest-like dialogue with the foreign," opening the way to "the 
appropriation of one's own ... as the encounter" (Heidegger, Holderlin's Hymn 142). The motel's boundary allows the foreign to be close by, reminding the visitor that the encounter with dwelling is always on the verge of returning to the unhomely.

Dwelling at the motel occurs as one passes through the motel's unhomeliness and comes to rest in what is homely within it. In an amplified sense No Country's protagonist Llewelyn Moss demonstrates this mode of comportment throughout the film as he repeatedly takes fleeting solace in even the briefest moments of safety offered by his lodgings. Although this example suggests a negative relation to the tragic, it still retains the vitalizing aspect. Here one sees the tragic transform the individual by urging him to become more aware. Less extreme circumstances too, such as a long drive or getting lost in a strange city, can place one at a personal edge, physiologically, environmentally, psychologically. In these moments, increased susceptibility to the homely are found as the vitality of familiar aspects of accommodation are felt to resonate with more force. In the motel this attentiveness is consummated in the coupling of individual need and the bounty of the room itself, where the modicum of requirements for living becomes exactly enough. This is to say, when separated from those familiar comforts of home, the basic amenities of the motel are frequently experienced as surprisingly satisfying and complete. In this appreciation one experiences a primal state of existence, discovering that in a reductive environment there is increased satisfaction found within the simplest of things. One's experience of the motel gains or loses intensity in correspondence with the motel's degree of dislocation as well as the guest's physical state and perceived sense of isolation. Many know this feeling of travel, where stressed surroundings and a taxed mind/body make crossing the threshold of a basically well-maintained motel room a passage into a sanctuary (regardless of its lack of beauty), where the emergence of the vulnerable aspects of one's life (i.e. sleeping, 
bathing, dressing, etc.) become possible. At this boundary the motel room announces itself as a place where pretense and defense may relax, holding open a space where the relief of a return to one's self may occur. Even with the encouragement of intensified conditions Heidegger reminds us that, "... to dwell in what is one's own is what comes last and is seldom successful and always remains what is most difficult" (Holderlin's Hymn 21). Here the reciprocation of the visitor is shown to be essential for dwelling.

The motel reveals its special betweenness when travelers give themselves over to the encounter. Here the hiatus found and facilitated by the limited circumstances of the motel can bring a satisfaction that appears to be incongruent with the material presence of the motel. In thinking about how the visitor and room come together to transcend the motel's banality, Hannah Arendt provides a possible explanation:

It is in the nature of the human surveying capacity that it can function only if man disentangles himself from all involvement in and concern with the close at hand and withdraws himself to a distance from everything near him (251).

So while the absence of more traditional features of beauty would appear to encourage surveying and separation, this deficiency is trumped by the absorbed coping of the individual as facilitated by the simple material comforts of the motel room. In this way the motel's banal amenities become focused involvements. However, one's relation to the motel goes further than focused involvement, as the motel also calls to one's body seductively with its minimal offerings. The softness and warmth of the bed, the refreshing spray of the shower, even the mindless relaxation of the television obscure the strangeness of the room and help to form a buffer against the insecurities beyond. In this way the motel overcomes itself, and with the visitor the strangely familiar becomes refuge. 
Despite the array of amenities that support dwelling in the motel, ultimately it seems that the bed becomes the focal point of this unique sanctuary and the prime mover toward becoming homely. Since the unappealing aesthetic qualities and limited space of most motel rooms do not invite lingering in the room except around times of engagement with the bed, the bed finds itself at the center of this exchange. The anchoring of the bed occurs both spatially and experientially through its basic location, dominant presence in the room, and fundamental materiality. The bed is a floating island of comfort and support for a weary body. When in proximity to the bed, the rest of the room and furnishings recede in importance and only emerge in times of necessity. The bed is like a nest, the location most likely to be associated with feelings of comfort, security, and being settled. In this manner the bed stands as the experiential center of the room. It offers accommodation for sleep, reading, television, sex, and other activities.

The power of the bed comes with physical contact. In these moments the bed draws on the essential needs of the body for comfort and support. In its sensuous physicality the bed has the capacity to provide both emotional support and physical satisfaction; the portal of the bed is the trigger for the transformation of the motel room into a homely place. Through the bed, one's experience confirms that the necessities of existence in a taxed state are minimal, and that in one's immediate environment little needs to be present in order to have feelings of connection, belonging, and a sense of place. Certainly more extensive relations to place are necessary to achieve depth in interaction and connection. Yet, despite the bed's visual appearance and surroundings, if it is clean, warm and accommodating, one easily becomes enmeshed and quickly satiated. With this enmeshment a blurring of subject and object occurs and the observer is subsumed as participant—or better, inhabitant. Thus, as a stage for a multitude of different encounters, the bed $i$ the motel room and the locus of its invitation to becoming homely. 
The motel's temporality points to the fact that, "we must ever learn to dwell" ("Building Dwelling Thinking” 159). This means that dwelling as becoming is our natural state and we must therefore always be re-settling and only for a while. The motel is a perfect vehicle for understanding this process. Standing in between the strange and the familiar lets the roadside motel spin the homely and the unhomely through the visitor to form the unity of dwelling. To visit the motel is not unlike Hercules' visit to the Ister where, "a guest is that foreigner who for a time becomes homely in a homely place foreign to them, and thus themselves bring what is homely for them into the homely of the foreign and are received by the homely of the foreign" (Heidegger, Holderlin's Hymn 140-141). In the motel, the visitor and locale too find unity through mutual transformation. The motel helps us "ever learn to dwell" because it asks that we reconsider what it is to be at home, and then demands that we adapt to a situation as dictated by circumstances, becoming satisfied not with what we want but rather with what the motel can give. And its offer is temporary. On the path toward dwelling welcoming the uncertain, the passing, the tragic, is our most basic and arduous task. Through exchange the motel teaches us that being-in-the-world is fundamentally transitional.

\section{Intervention}

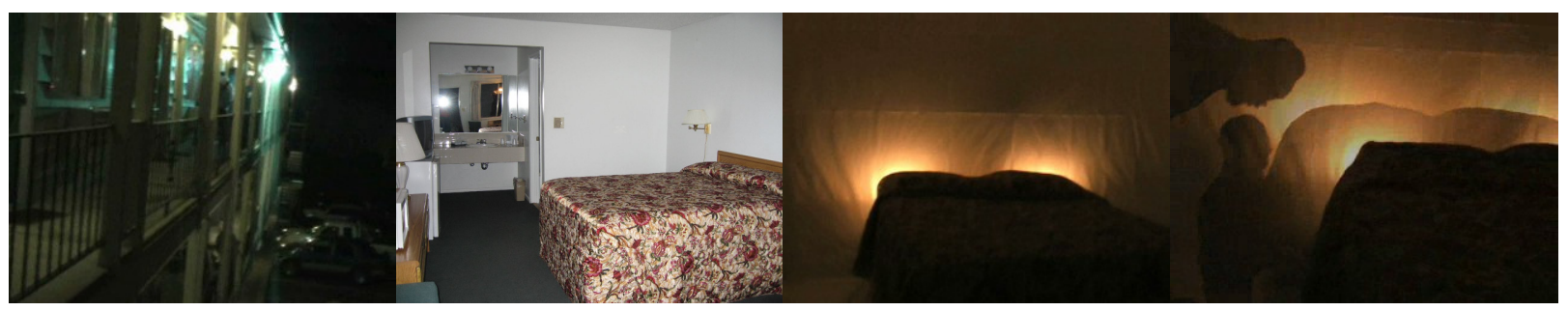

Figure 1: "Dido and Aeneas" by Randall Teal as part of the group exhibit In(n) and Out of Nowhere, Pullman, WA. 
Undertaking the motel installation, I sought an interpretive intervention that would be both open in its reading and committed in its feeling. The intervention was an effective follow up to writing as it allowed an examination of one particular room in one particular motel. Further, it returned to the material encounter and asked that I translate the thoughts of the paper into physical form.

Thinking about the installation I became primarily interested in this ability of the motel to provide sanctuary through its very reductiveness. I did not want to add to or "fix" the room, but rather to emphasize more fundamentally the "standard" motel room offering a sensuous moment of bodily comfort. I also hoped to achieve this in a manner that was slightly odd so as to evoke that subtle yet uncanny tinge of the tragic. Of particular interest was the role of the bed in catalyzing the transformation of the visitor from observer to inhabitant. The basic notion of the installation started with obscuring the institutional blandness of the particular room I was working with (which was predominantly white). Since visitors here would not be staying in the space, and therefore not assisting the room in transcending its own banality, I sought to reduce the environment to the barest of detail myself and focus on the sheltering volume of the room itself in order to facilitate a more ephemeral state. I accomplished this goal by cloaking all that was not white in the room with white plastic film-the bed being the exception. This move served to de-emphasize the banal elements of the room, which appeared mainly in the form of particle board furniture and forest green industrial carpeting, and highlight the bed. In this way the bed then became the heart of the space and focal point for encounter. On one level its floral bedspread alluded to the interconnected family of all motel beds, but more importantly, on a purely sensorial level, its red floral pattern reached out to the visitor as the one spot of color and softness in the entire room. This reduction served to magnify the material and sensual qualities of 
the bed through its promises of bodily engagement. I hoped that in this reduced environment I would effectively frame what was already there, with the bed becoming a real (not conceptual) point of connection for visitors, just as it might be for a traveler. In short, my primary intention was to create an experiential encounter with this (new) environment that responded to the particular givenness of this motel room. My primary goal was for an experience that was driven by sensory engagement through light, texture, color and sound. Finally, in order to emphasize (and encourage) the phenomenal encounter with this intervention, my conceptual thinking was not explained outright.

As one further addition to the sensuousness of the space, Henry Purcell's Dido and Aeneas was left playing in the room. This was done in order to shape a particular mood in the space. The music selection was primarily inspired by the notion that the rich sonority of Purcell's opera would further enhance the sensuousness of the bed and its floral covering, tingeing it solemn by its minor key. This particular work had conceptual significance as well, leaving a clue as to the tragic undertones that informed this installation. The Dido and Aeneas story tells a tale of travel, visitation, and love where the departure of the traveler/lover is fated (Dido cannot keep Aeneas) and these circumstances culminate in Dido's death. Although I did not explain this, I believed that the pregnancy of the story as conveyed through the mood of the music would provide another layer of depth to the experience. If anyone made the intellectual connection between the score and the other sensuous qualities of the installation, this would come as an extra reward.

Through erasure and reframing my desire was to momentarily project visitors, by way of this motel room's specific sensuality, to a particular transcendent experience of "the motel." The hope was that in this transcendent moment one would experience, as Nietzsche suggests, “... a 
metaphysical comfort [that] tears us momentarily from the bustle of changing figures. We are really for a brief moment primordial being itself ..." (104). In this way the installation was meant to disorient and focus at the same time, hinting at the transcendent power of the sensuous and the poignant. In the end a more primordial vision of the motel through the modulation of this specific site of dwelling and its sensuous reality was the goal. As the installation only lived for one night in this motel, it underwent that same temporary dwelling as the traveler, giving a unique identity to this room, if only momentarily.

\section{Conclusion}

Visions of the motel straddle a line between the familiar and the strange. Outdated appearances, blandness, and isolation frequently evoked by the motel, can result in feelings of separation and anxiety and yet be strangely familiar. Film, particularly, has elaborated on these themes on many occasions, feeding the mythology as the motel is shown as a place on the edge of civility where the unthinkable is always possible. This coloring of darkness, anonymity, and tragedy hang over the motel, and yet ultimately, it seems the basic refuge offered by the motel room itself warrants return, with the validity of this return being affirmed by the basic embodied satisfaction of bathing, shelter, and sleep, intensified by this reductive environment.

Eventually we find that this delicate balance of the uncanny, the raw, the sensual, the haphazard, the simple, and the seductive becomes the motel's own unique un/homely identity. Perhaps the motel is analogous to other such visceral phenomena as punk rock, the writing of Charles Bukowski, or a Jim Jarmusch film, where the power of reduction and imperfection becomes a means of communication and point of connection. Like these communications from the edge the motel is also special because it stands outside the traditional canons of beauty, 
affording beautiful encounters in its ability to become homely. With this ability the motel becomes a primitive site of dwelling. In this role the motel encompasses both the homely and unhomely and in so doing asks one to come back into their own by finding home in that which is not home. Through becoming homely, relations, processes, and events that occur between people, places, and things are heightened. In this way even the most basic things become tinged with significance.

In the end the motel shows us that, "being unhomely is no mere deviance from the homely, but rather the converse ..." (Heidegger, Holderlin's Hymn 74). As humans we experience this in-between phenomenon when we stand amidst these opposites allowing them to coalesce in our becoming. Here we experience dwelling as an activity that is both strange and familiar. The motel is a journey into the homely.

\section{Notes}

${ }^{1}$ Installation took place in March 2007.

2 See William McNeill and Julia Davis' translation of Martin Heidegger's Holderlin's Hymn "The Ister," where heimisch is rendered as "homely" and unheimisch as "unhomely."

3 In Part 2 of Holderlin's Hymn "The Ister." Heidegger discusses at length how humans are the "uncanniest of the uncanny" because they are fundamentally not at home and "that their care is to become homely" (51-74).

\section{Works Cited}

Arendt, Hannah. The Human Condition. The University of Chicago Press: Chicago, 1958.

Bly, Laura. “Come Inn Off the Highway.” USA Today. 2003. December 2006. http://www.usatoday.com/travel/destinations/road/2003-10-10-holiday-inn_x.htm 
Bottle Rocket. Dir Wes Anderson. Perf. Luke Wilson, Owen Wilson, Ned Dowd, Shea Fowler, Haley Miller, Robert Musgrave, Andrew Wilson, James Caan. 1996. DVD. Criterion Collection 2008.

Curtis, Wayne. "No Room at the Inn: Whatever happened to the NO VACANCY sign?" The Atlantic Monthly. 288.4 (2001): 32-35. December 2006. $<$ http://www.theatlantic.com/doc/prem/200111/curtis $>$

Frampton, Kenneth. "Towards a Critical Regionalism.” Ed. Hal Foster. The Anti-Aesthetic: Essays on Postmodern Culture. New York: New Press, 2002.

French, Phillip. "This looks a nice place to stop ..." The Observer. 2000. July 2008. <http://www.guardian.co.uk/film/2000/dec/17/features.review.>

Heidegger, Martin. "Building Dwelling Thinking." Trans. Albert Hofstadter. Poetry, Language, Thought. New York: Harper \& Row, 1971. 145-162.

—. Holderlin's Hymn “The Ister.” Trans. William McNeill and Julia Davis. Bloomington: Indiana University Press, 1996.

L.A. Confidential. Dir. Curtis Hansen. Perf. Kevin Spacey, Russell Crowe, Guy Pearce, James Cromwell, Kim Basinger, Danny DeVito, David Strathairn. 1997. DVD. Warner Home Video 2008.

Leaving Las Vegas. Dir. Mike Figgis. Perf. Nicolas Cage, Elisabeth Shue, Julian Sands Richard, Lewis Steven Weber, 1995. DVD MGM Home Entertainment 2000.

Lost Highway. Dir. David Lynch. Perf. Bill Pullman, Patricia Arquette, John Roselius, Louis Eppolito, Robert Loggia, Robert Blake. 1997. DVD. Universal Studios 2008.

The Motel. Dir. Michael Kang. Perf. Jeffrey Chyau ,Sung Kang, Jade Wu, Samantha Futerman, Alexis Chang. 2005 DVD. Palm 2007.

Nietzsche, Friedrich. The Birth of Tragedy and the Case of Wagner. Trans. Walter Kaufmann. New York: Random House, 1967.

No Country for Old Men. Dir. Ethan Coen and Joel Coen. Perf. Tommy Lee Jones, Javier Bardem, Josh Brolin, Woody Harrelson, Kelly Macdonald. 2007. DVD. Miramax 2008.

Norberg-Schulz, Christian. Architecture: Presence, Language, Place. Milan: Skira, 2000.

-. The Concept of Dwelling: On the Way to a Figurative Architecture. New York: Rizzoli, 1985.

—. Genius Loci: Towards a Phenomenology of Architecture. New York: Rizzoli, 1980. 
Paris, Texas. Dir. Wim Wenders. Perf. Harry Dean Stanton, Dean Stockwell, Aurore Clement, Hunter Carson, Nastassja Kinski. 1984. DVD. $20^{\text {th }}$ Century Fox 2004.

Psycho. Dir. Alfred Hitchcock. Perf. Anthony Perkins, Janet Leigh, Vera Miles, John Gavin, Martin Balsam, John McIntire, Simon Oakland. 1960. DVD. Universal Studios Home Entertainment 2005.

A Touch of Evil. Dir. Orson Wells. Perf. Charlton Heston, Janet Leigh, Orson Welles, Joseph Calleia, Akim Tamiroff, Joanna Cook Moore, Ray Collins, Dennis Weaver, Valentin de Vargas. 1958. DVD. Universal Studios 2008.

Vesely, Dalibor. Architecture in the Age of Divided Representation: The Question of Creativity in the Shadow of Production. Cambridge: MIT Press, 2004.

The Way of the Gun. Dir. Christopher McQuarrie. Perf. Ryan Phillippe, Benicio Del Toro, Juliette Lewis, Taye Diggs, Nicky Katt, Geoffrey Lewis, Dylan Kussman, Scott Wilson, Kristin Lehman, James Caan. 2000. DVD. Lions Gate 2001. 